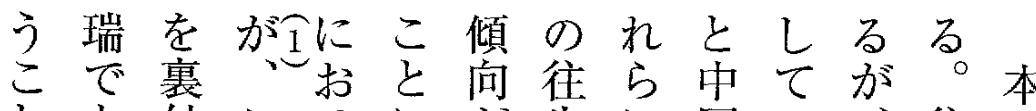
亡あ付こけに等生に国の、往稿 でる约のる何見伝何の夢そ生で あるる往夢らえのら往のの人は ろそも生中加て中加生重中の往 うのの伝体のくでの伝要で臨生 加紫でに験重るは傾に性も終伝 中雲あおの要っ紫向おを紫にに

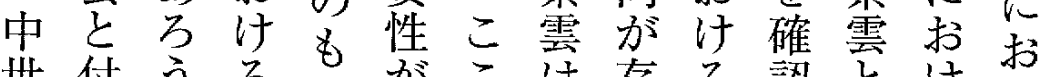

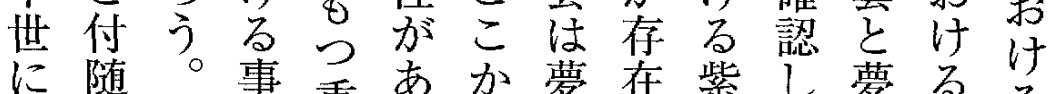
に随。事重あか夢在紫し夢るる 招的奇例重つ要た程雲てと来紫 けに瑞も要た私にるのいの迎算 る夢の中性のは確か出き関の雲 夢が中世は岕、認を現た係奇夢 の語でに前は紫さ確古い性瑞夢

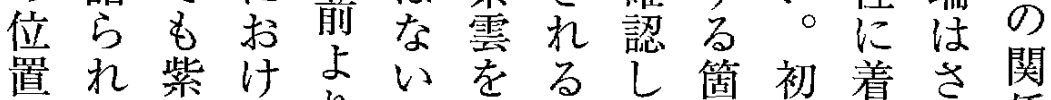
付る雲るりか夢も所め自ま係 けとは夢注と中の名にしざに を言特の目考でです取日亩、 こうにもさえ見あるり本表にい のこ高つ机るるるると現表て よと位重て とと将往方現考 うはな要い中いい日生法さ察

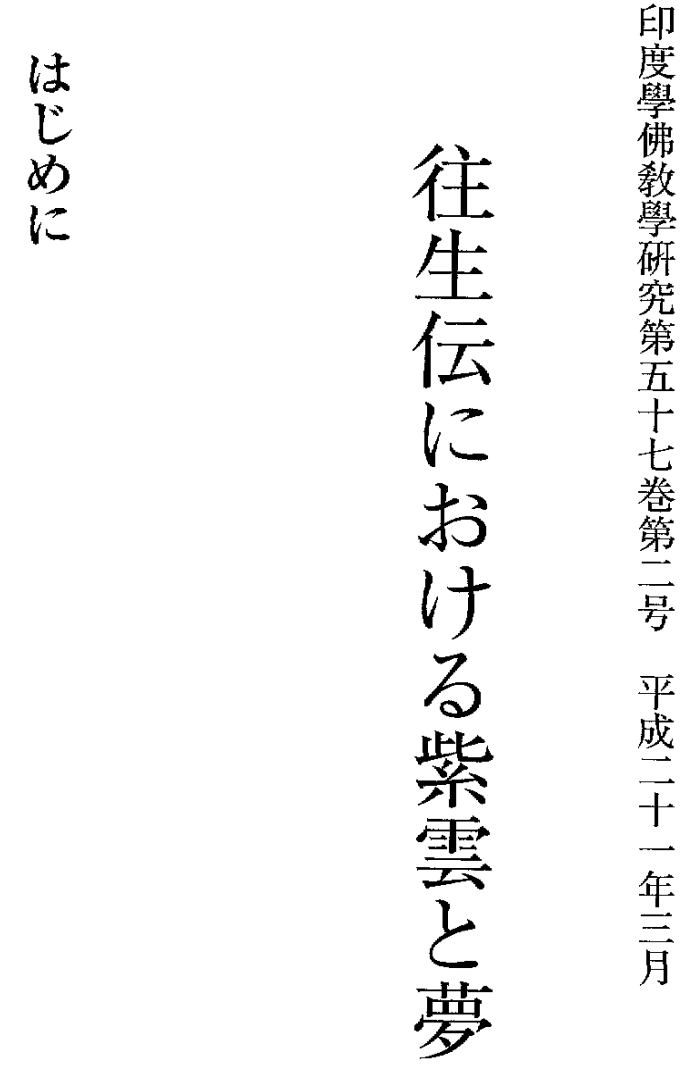
など奇性る世うう本そ伝と氺守

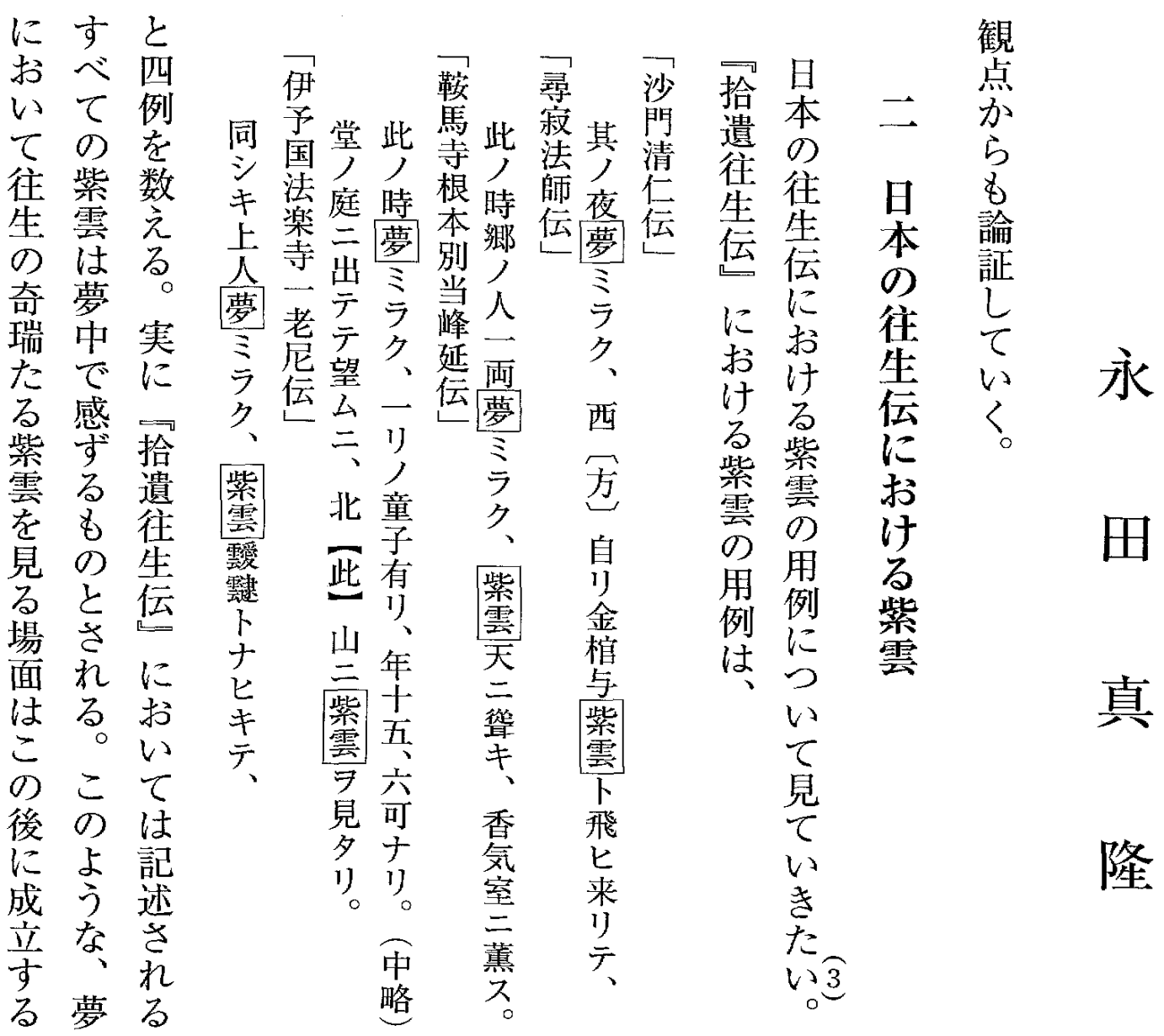


かく雲でと

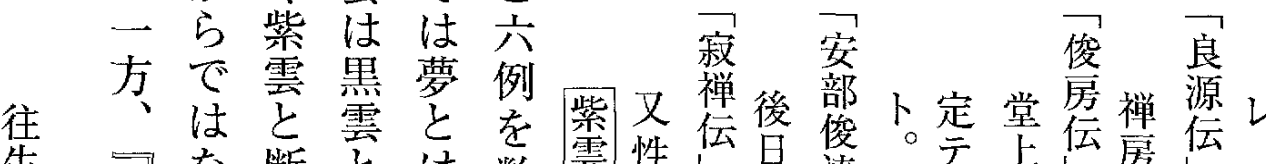

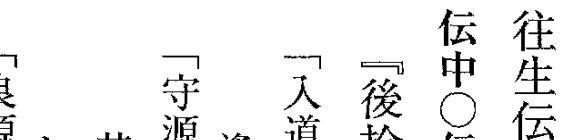

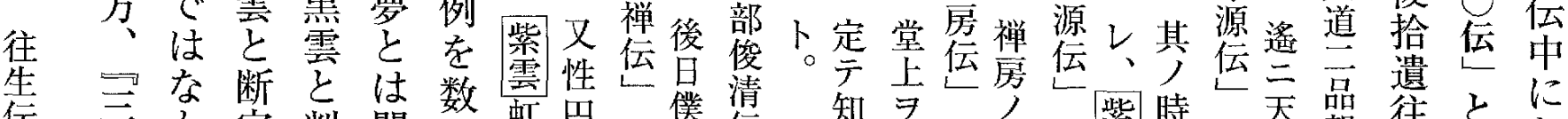

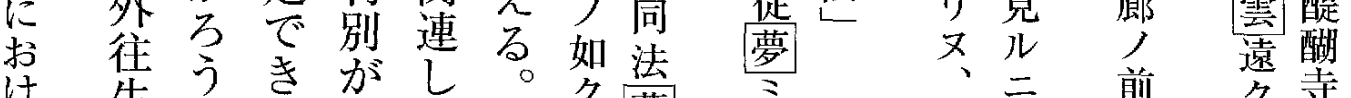

け 生方き出し

唯伝加な出な来い入䑅

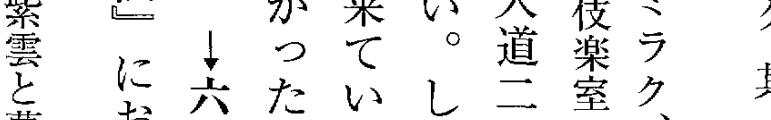

夢打六たいし主室ク、其

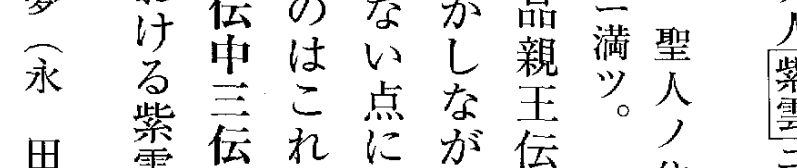

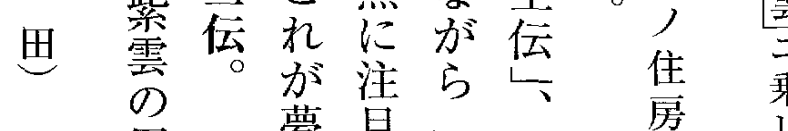

伝

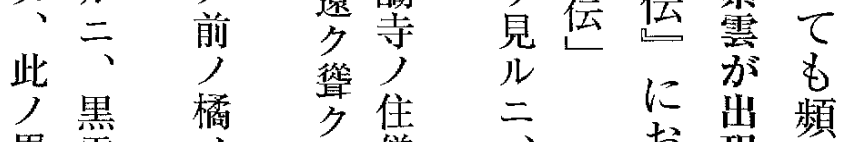

黑雲 $>$ 僧出頻

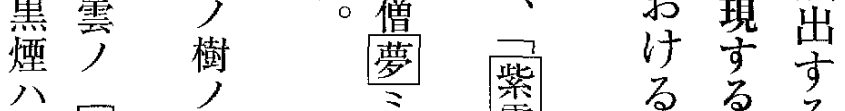

八朵上蕓紫伝る

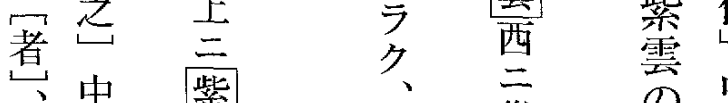

是

雲再

之現

瑞

は性と

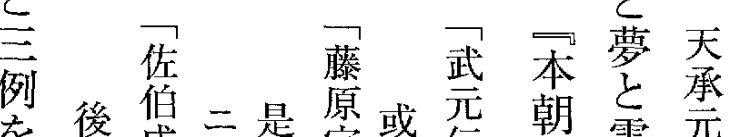

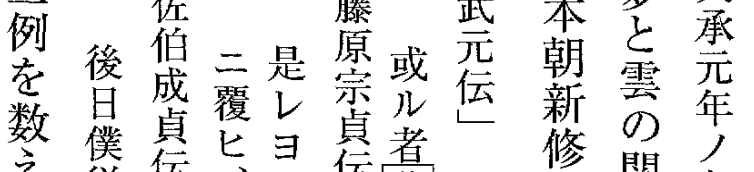

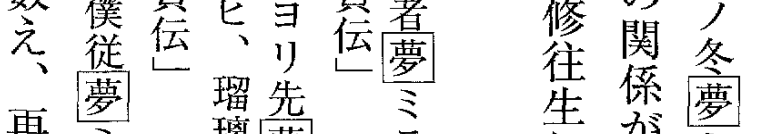

び再夢

夢 ク、卡語

紫紫紫当棓紫

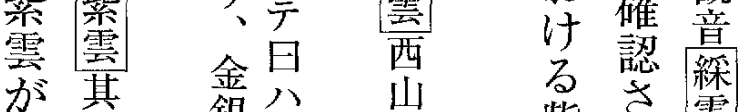

が其銀八监

関墓㷊ク、覆

係墓索為老

云覆 出家

語 復家

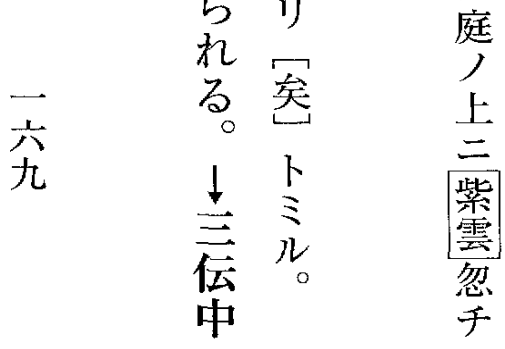

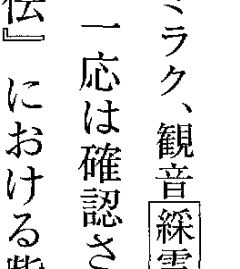

紫蕓葶

薄五例汀源永鬲薩 溥紫州念俊或助暁品其摩

と数雲賀退伝公酒親日沙

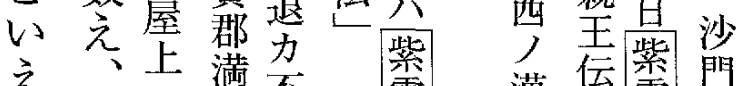

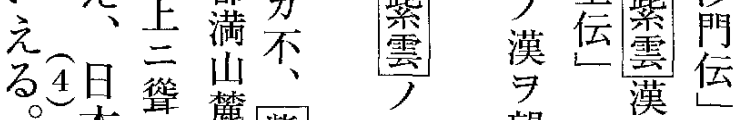

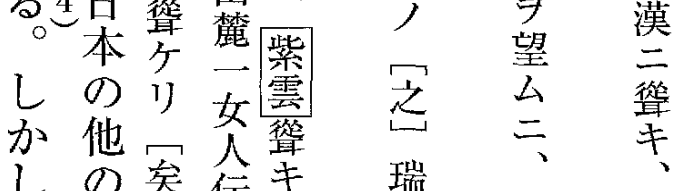
紫往㞺伝来 瑞遙西

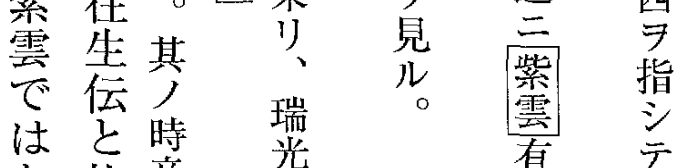

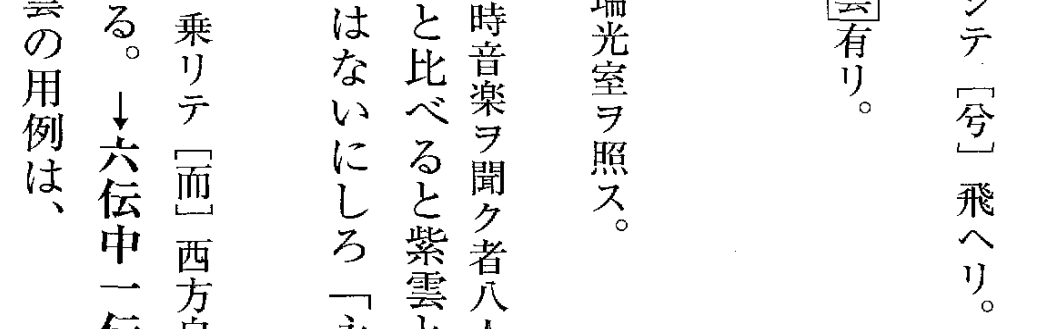

伝方永雲公

覚夢于

来伝のリ

リに篦 


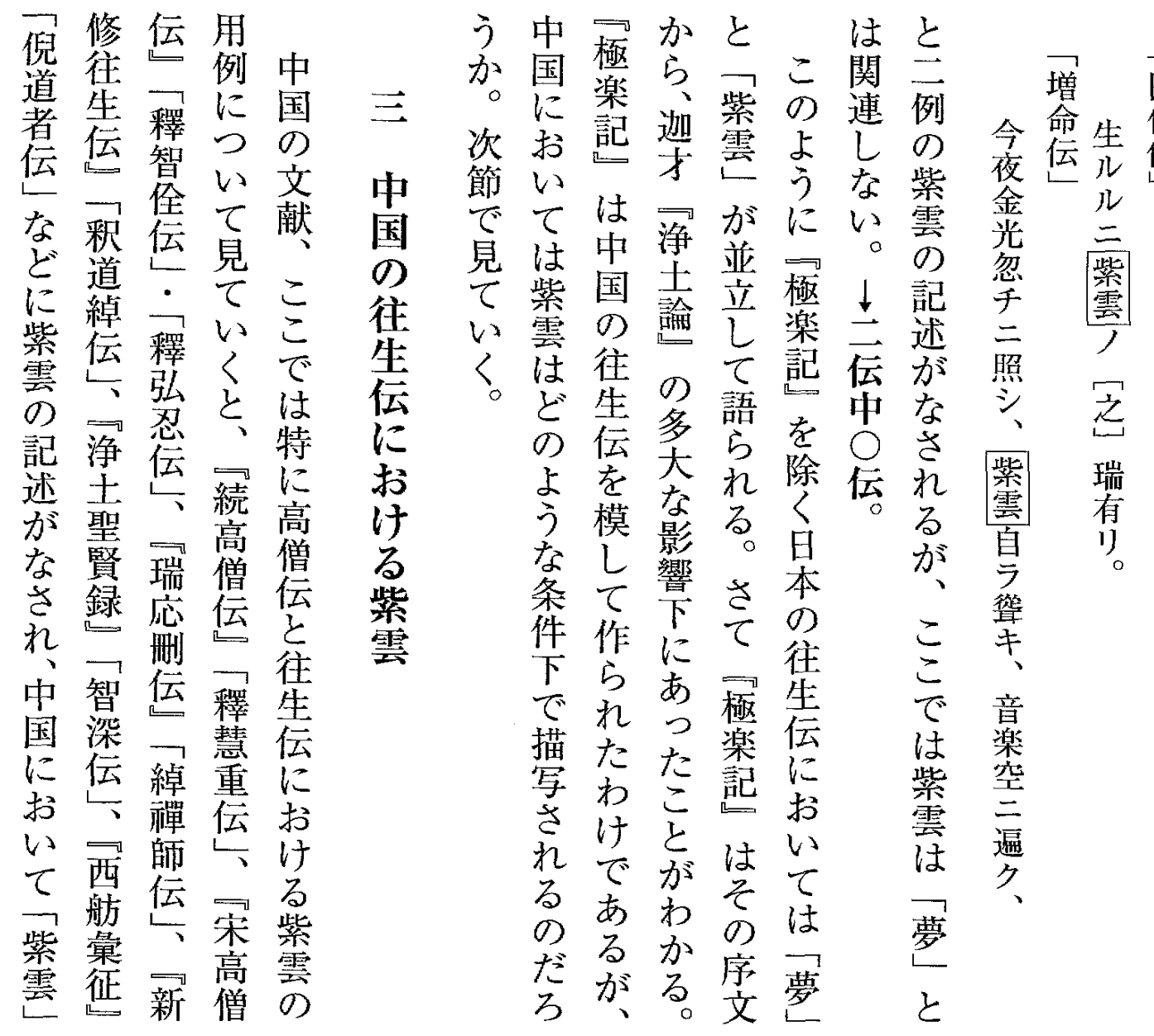

\section{紫 極}

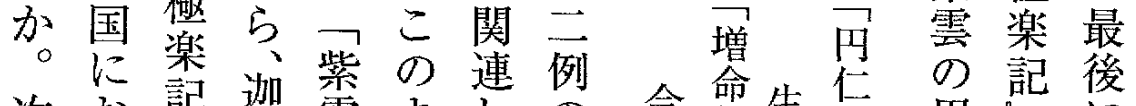

次打記拈雲よしの含伝生伝用品に往

例 希

て極初拉

く楽の る

と, 記 往 紫

は伭夢

う市永

ろ 蔍思

う保

加龍

$=\sqrt{2}$

れる

に早

い本

て 往

\&生

とに夢てばのとま意しのに

の語信い河意はり味日体共夢 近 5 仰る東味違中合本験通中 似れにと仁合い国いののがしに 的る連は氏い、にの中重てお 視よないはがあお堂世要見い 点うる元日强くけうにならて がなし、本いまるもも打意れ不 中杲も夢の往日で夢のい味る思 国本のを往日もはかてを。議 ににと聖生本霊、あは持古な お古すな伝に証しつ中つく経 け代るるのおにばた国も加験 万加。次夢けすしのにのら老 むらつ元にるきばで見と夢す もあまとつ夢ず現はららさはる のるりのいの、実なれれ霊と 之夢可て特なといるて的い はに古信っ性ん混吕夢きなう 違対事装仏にら同とへた意表 す記置教関か古考のの味現 たる匹と的しのるえ関でをは 独に可色て前 日ら市持日 自外条な彩、兆本机方吉本 性的本書をたとのるは。 を現書原おとしそ。少しこ中 持実督 11 方てれっしかで国
連せみもし本と 性なるのてにい 四の加のたおう 無つこあ関い語 さた極ろわては に原楽うる見し よ因記かとらば るは心いれし も、に次うるば のこお節こよ確 にのいでとう認 他中て詳はにさ な国紫しなっれ $ら に$ 雲くい夢る なおと考。とと いけ夢えこがい るのたれ特え 往関いは段る。 生連。如 伝守ま何紫 ᄂ のるたな雲加 紫 傾翻る登し 雲向つ理場こ 七 とがて 由 こ 夢見おに条で のい\&よ件は 関たんると日 
な、強一、本

味夢。日稿

往をのし本に 生 持中かのお 伝つでし往い にて語中生て 势いら国伝結 るたれにに論 紫。るお打を 雲こいいつ 夢 氽

田

とててけ
はは紫る

杲こ零亭

の傾夢 れ

中向のば

世はな以

に見か下

捛らでの

い水語よ

てならう

はいるに

特○るな

に傾 万

重向う

の述迎な生前に生仁しなな現奇ち

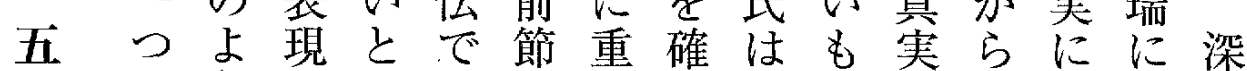
でうがいので視証往のと日見よく 小あな日うみ述さす生でし本るり関 結る日本こ確べれる夢あてでと往係 と本でと認た亩にる捉はこ生し

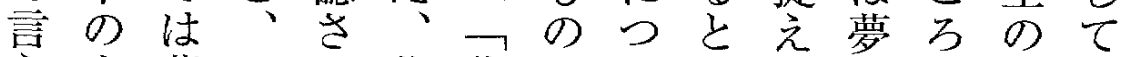

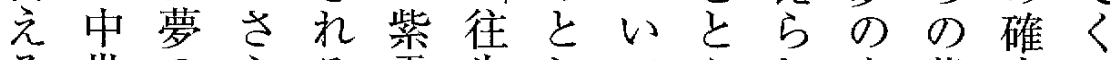
る世のらる雲生してら和中紫定る

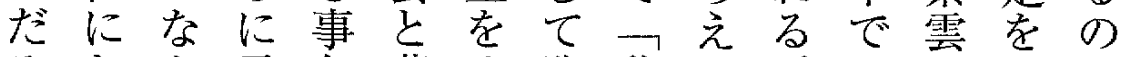
ろお方言象夢め臨称る。の食証で うけで党でがぐ終名こむ出光明あ るのばあ関る時念とし来明劣る 夢み、り係最に仏も万事でる。 の語紫中寺大报にあ夢さながな 位ら雲国るのけよるで光け、る

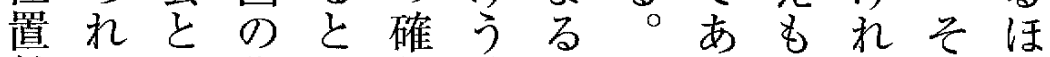
付るい往い証瑞易こる往ばれど けとう生うと雲行のが生なは、 をい比伝傾な化よ故をら中往 咅う較で向る芳がうに確な国生 付こ的はは香進なよ定いに伝 けと上確日との者中り李。扔は るは位認本す出中で確るしい来 も、のさのる現、河かょかて迎 の前来れ往。以往東らうしはの

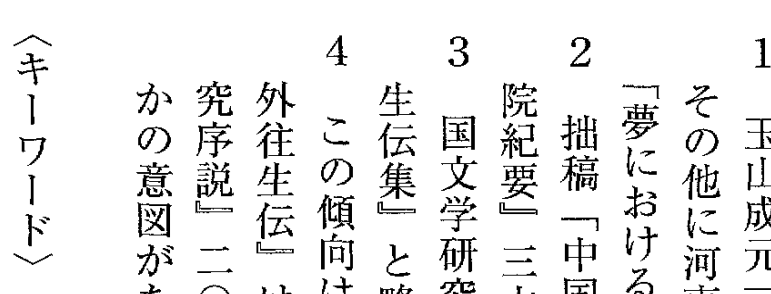

往あ○はは略究亲国奀東中

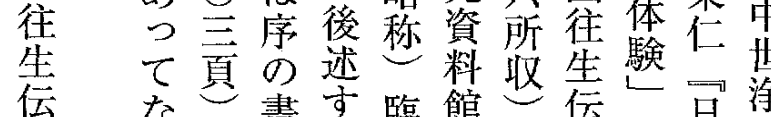
な書守臨館位百浄 さっ栻る川編参にで星圭

紫机まが霞書照扔は河の教

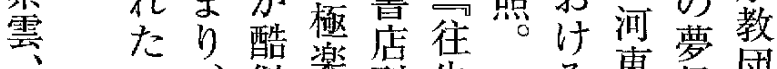

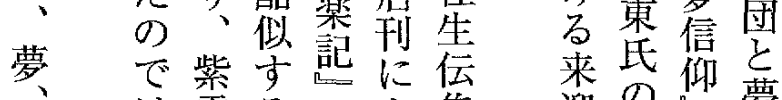

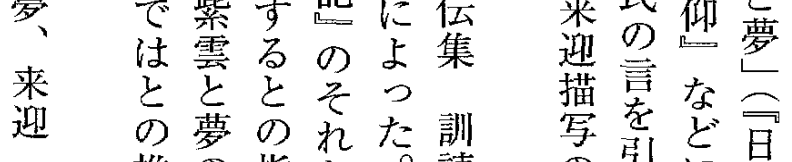
推の指と。読市㛭に早

佛
孝
学
学
院 測関 摘同頁 . 架連方様数解

で性京少題

ま方雱略

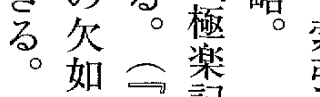

も往記

な生と

え伝气

篇

雍
変祭仙

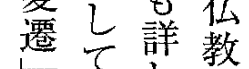

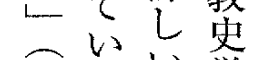

研方的学

整 桀士
学

学
第 所

四収
の特こ一

も別充こ

意人出こ

味物来京

がでるら

中あ

国るま紫

とこた雲

日とこは

本かれ特

でらは别

はも紫に

変傍雲重

質証 が要

しで語な

て ら奇

いる れ 瑞

る。るで

こさ往あ

と方生る

がに妘主

窥いの位

方主置

夢公方 